\title{
Effect of a $\gamma$-aminobutyric acid-enriched dairy product on the blood pressure of spontaneously hypertensive and normotensive Wistar-Kyoto rats
}

\author{
Kazuhito Hayakawa $^{1}{ }^{*}$, Masayuki Kimura ${ }^{1}$, Keiko Kasaha ${ }^{1}$, Keisuke Matsumoto ${ }^{1}$, Hiroshi Sansawa ${ }^{1}$ \\ and Yukio Yamori ${ }^{2}$ \\ ${ }^{1}$ Yakult Central Institute for Microbiological Research, 1796 Yaho, Kunitachi-shi, Tokyo 186-8650, Japan \\ ${ }^{2}$ International Center for Research on Primary Prevention of Cardiovascular Diseases, 86-2 Shimobara-cho Jodoji, \\ Sakyo-ku, Kyoto 606-8413, Japan
}

(Received 22 October 2003 - Revised 29 April 2004 - Accepted 11 May 2004)

\begin{abstract}
We investigated the blood-pressure-lowering effects of $\gamma$-aminobutyric acid (GABA) and a GABA-enriched fermented milk product (FMG) by low-dose oral administration to spontaneously hypertensive (SHR/Izm) and normotensive Wistar-Kyoto (WKY/Izm) rats. FMG was a non-fat fermented milk product produced by lactic acid bacteria, and the GABA contained in FMG was made from the protein of the milk during fermentation. A single oral dose of GABA or FMG $(5 \mathrm{ml} / \mathrm{kg} ; 0.5 \mathrm{mg} \mathrm{GABA} / \mathrm{kg})$ significantly $(P<0.05)$ decreased the blood pressure of SHR/Izm from 4 to $8 \mathrm{~h}$ after administration, but did not increase that of WKY/Izm rats. The hypotensive activity of GABA was dose-dependent from 0.05 to $5.00 \mathrm{mg} / \mathrm{kg}$ in SHR/Izm. During the chronic administration of experimental diets to SHR/Izm, a significantly slower increase in blood pressure with respect to the control group was observed at 1 or 2 weeks after the start of feeding with the GABA or FMG diet respectively $(P<0.05)$ and this difference was maintained throughout the period of feeding. The time profile of blood-pressure change due to administration of FMG was similar to that of GABA. FMG did not inhibit angiotensin 1-converting enzyme. Furthermore, an FMG peptide-containing fraction from reverse-phase chromatography lacked a hypotensive effect in SHR/ Izm rats. The present results suggest that low-dose oral GABA has a hypotensive effect in SHR/Izm and that the hypotensive effect of FMG is due to GABA.
\end{abstract}

$\gamma$-Aminobutyric acid: Fermented milk: Blood pressure: Spontaneously hypertensive rat

High blood pressure is the leading risk factor for CVD, which remains one of the most important public health problems in the world (Guidelines Subcommittee of the World Health Organization-International Society of Hypertension, 1999; International Society of Hypertension Working Group, 2003). The development of hypertension is caused by several factors, including diet and lifestyle. It is well known that nutritional factors influence blood pressure; for example, excessive salt and alcohol intake may lead to an increase in blood pressure (Suter et al. 2002). Studies using the Dietary Approaches to Stop Hypertension (DASH) diet demonstrate that a diet rich in fruits, vegetables, low-fat dairy products, fibre and minerals $(\mathrm{Ca}, \mathrm{K}$ and $\mathrm{Mg}$ ) significantly lowers blood pressure and is effective as the first-line therapy (Moore et al. 2001; Whelton et al. 2002; Akita et al. 2003). Many studies have addressed the effect of minerals on blood pressure, but few have assessed the influence of a small quantity of an amino acid as a dietary supplement.
$\gamma$-Aminobutyric acid (GABA) is an amino acid that has long been reported to lower blood pressure by intravenous administration in experimental animals (Takahashi et al. 1955; Stanton, 1963; Lacerda et al. 2003) and in human subjects (Elliott \& Hobbiger, 1959). However, the effect of dietary GABA has attracted little attention as a factor that may influence blood pressure, and it is not known whether low-dose oral administration of GABA affects blood pressure. GABA is present in many vegetables and fruits but not in dairy products. We developed a fermented low-fat milk product containing GABA (FMG) by using two types of lactic acid bacteria. Although GABA is not normally detectable in milk, it was made from the protein of the milk by the metabolic action of the lactic acid bacteria.

Our previous study showed that FMG had a blood-pressure-lowering effect in mildly hypertensive patients (Inoue et al. 2003). Although various fermented milk and cheese products have stronger hypotensive effects, owing to

\footnotetext{
Abbreviations: ACE, angiotensin I-converting enzyme; FMG, $\gamma$-aminobutyric acid-enriched fermented milk; GABA, $\gamma$-aminobutyric acid; SBP, systolic blood pressure; SHR, spontaneously hypertensive rats; WKY, Wistar-Kyoto.

* Corresponding author: Dr Kazuhito Hayakawa, fax +81 42577 3020, email kazuhito-hayakawa@yakult.co.jp
} 
inhibition of angiotensin I-converting enzyme (ACE), it is not clear whether the effect of FMG depends on GABA or other components.

Therefore, in the present study we compared the effects of single-dose or chronic oral administration of GABA or FMG on the blood pressure of spontaneously hypertensive rats (SHR). We determined the ACE-inhibiting activity of FMG to clarify the hypotensive mechanism of this product; we then determined the minimum effective dose and the dose-response curve for the hypotensive action of GABA.

\section{Materials and methods}

\section{Chemicals and reagents}

GABA and other reagents were of analytical grade and were purchased from Sigma Chemical Co. (St Louis, MO, USA).

\section{Preparation of fermented milk}

FMG (Table 1) was produced by fermenting skimmed cows' milk with two starters, Lactobacillus casei strain Shirota and Lactococcus lactis YIT 2027 (Kimura et al. $2002 a$ ). The concentration of GABA in FMG was $1 \mathrm{mmol} / \mathrm{l}$.

\section{Animals and diets}

SHR (SHR/Izm) and normotensive Wistar-Kyoto rats (WKY/Izm) (male, 14 weeks old, weighing 310-370 g

Table 1. Composition of $\gamma$-aminobutyric acid (GABA)-enriched fermented milk

\begin{tabular}{lr}
\hline Ingredient & Amount \\
\hline Moisture $(\mathrm{g} / \mathrm{kg})$ & 888 \\
Protein $(\mathrm{g} / \mathrm{kg})$ & 22 \\
Fat $(\mathrm{g} / \mathrm{kg})$ & $\mathrm{nd}$ \\
Ash $(\mathrm{g} / \mathrm{kg})$ & 5 \\
Carbohydrate $(\mathrm{g} / \mathrm{kg})$ & 81 \\
Fibre $(\mathrm{g} / \mathrm{kg})$ & 4 \\
Na $(\mathrm{mg} / \mathrm{kg})$ & 381 \\
Ca $(\mathrm{mg} / \mathrm{kg})$ & 742 \\
Free amino acids $(\mathrm{mg} / \mathrm{kg})$ & \\
GABA & 102 \\
Asp & 50 \\
Thr & 28 \\
Ser & 9 \\
Glu & 14 \\
Pro & 83 \\
Gly & 19 \\
Ala & 35 \\
Cys & 0 \\
Val & 29 \\
Met & 6 \\
lle & 15 \\
Leu & 26 \\
Tyr & 4 \\
Phe & 9 \\
Lys & 30 \\
His & 11 \\
Arg & 6 \\
Energy $(\mathrm{kJ} / \mathrm{kg})$ & 1340 \\
\hline
\end{tabular}

nd, not detected. for the single oral administration experiment (Expt 1); 6 weeks old, weighing $145-160 \mathrm{~g}$ at the beginning of the chronic administration experiment (Expt 2)) were purchased from Japan SLC, Inc. (Shizuoka, Japan), the breeder for the Disease Model Cooperative Research Association (Kyoto, Japan). Izm is the original strain type of SHR established by Okamoto \& Aoki (1963). The animals were divided into four groups of six animals each in Expt 1 and three groups of ten animals each in Expt 2. The diets were standard laboratory diet (MF diet; Oriental Yeast Co. Ltd, Tokyo, Japan) in Expt 1 and modified AIN-93G diet (Table 2; Oriental Yeast Co. Ltd) in Expt 2. All animals received tap water ad libitum and were housed under a $12 \mathrm{~h}$ light-dark cycle (lights on 08.30 to 20.30 hours). An automatic air conditioning system (Air Handling Unit TUC-244BH, Toyo Engineering Works Ltd, Tokyo, Japan) controlled the temperature at $24 \pm 2{ }^{\circ} \mathrm{C}$ and the humidity at $60 \pm 5 \%$. Rats were acclimated to the housing conditions for at least 1 week before the start of the experiments. The present study was conducted in accordance with the Guide for the Care and Use of Laboratory Animals, as adopted by the Committees for Animal Experiments of the Yakult Central Institute.

\section{Dosage}

Expt 1. FMG ( $5 \mathrm{ml} / \mathrm{kg}$ body weight), a fraction containing the peptides from FMG $(5 \mathrm{ml} / \mathrm{kg})$, a suspension $(60 \mathrm{ml} / \mathrm{l})$ of skimmed milk powder $(5 \mathrm{ml} / \mathrm{kg}$ body weight), GABA $(0.05,0.50$ or $5.0 \mathrm{mg} / \mathrm{kg}$ body weight $)$ or captopril (10 mg/kg body weight) were given orally to SHR/Izm and WKY/Izm rats (six per group) by stomach tube between 09.30 and 10.00 hours. GABA, skimmed milk powder and captopril were dissolved in physiological saline $(9 \mathrm{~g} \mathrm{NaCl} / \mathrm{l})$. The dose of captopril (a typical ACE inhibitor) as a positive control was chosen so as to have a similar magnitude of blood-pressure-lowering effect as the level of FMG found in SHR/Izm.

Table 2. Composition $(\mathrm{g} / \mathrm{kg})$ of the experimental diets

\begin{tabular}{lccc}
\hline Diet. .. & Control & GABA & FMG \\
\hline Maize starch & 392 & 392 & 392 \\
Casein & 195 & 195 & 155 \\
Dextrinized maize starch & 132 & 132 & 132 \\
Sucrose & 100 & 100 & 40 \\
Soyabean oil & 70 & 70 & 70 \\
Cellulose powder & 50 & 50 & 50 \\
Mineral mixture* & 35 & 35 & 35 \\
Vitamin mixture† & 10 & 10 & 10 \\
L-Cystine & 3 & 3 & 3 \\
Choline bitartrate & $2 \cdot 5$ & $2 \cdot 5$ & 25 \\
tert-Butylhydroquinone & $0 \cdot 014$ & 0.014 & 0.014 \\
NaCl & 10 & 10 & 10 \\
GABA & - & 0.1 & - \\
FMG & - & - & 100
\end{tabular}

GABA, $\gamma$-aminobutyric acid; FMG, $\gamma$-aminobutyric acid-enriched fermented milk.

*AIN-93G-MX; Oriental Yeast Co., Tokyo, Japan.

†AIN-93G-VX; Oriental Yeast Co.

†Freeze-dried FMG (GABA-enriched fermented milk; FMG was modified so that carbohydrate and moisture were 30 and $939 \mathrm{~g} / \mathrm{kg}$ respectively. The remaining composition was not altered). 
Expt 2. The basal diet was modified AIN-93G containing $\mathrm{NaCl}(10 \mathrm{~g} / \mathrm{kg}$; Table 2). For 3 weeks, SHR/Izm rats were fed a basal diet (control, group 1), or a diet containing freeze-dried FMG $(100 \mathrm{~g} / \mathrm{kg}$ ) (final concentration of GABA $0 \cdot 1 \mathrm{~g} / \mathrm{kg}$, group 2$)$ or GABA $(0 \cdot 1 \mathrm{~g} / \mathrm{kg}$, group 3$)$. The animals were maintained on the basal diet before the experiment.

\section{Measurement of blood pressure and heart rate}

At $0,4,8$, and $24 \mathrm{~h}$ after a single oral administration of the sample solutions, individual rats were placed in a constanttemperature box at $37^{\circ} \mathrm{C}$ for a few minutes, and then systolic blood pressure (SBP) and heart rate were measured by the tail-cuff method using a blood pressure analyser (BP-98A; Softron Co. Ltd, Tokyo, Japan) connected to a personal computer (Mebius series; Sharp Co., Tokyo, Japan). To assess the hypotensive effects of different doses of GABA alone, SBP and heart rate were measured 0 and $4 \mathrm{~h}$ after a single administration. During chronic administration (Expt 2), SBP and HR were measured once per week.

\section{Measurement of angiotensin I-converting enzyme inhibitory activity}

ACE inhibitory activity was measured by the method of Cushman \& Cheung (1971), with modifications. Each test sample was centrifuged at $6000 \mathrm{~g}$ for $10 \mathrm{~min}$, and the supernatant fraction was adjusted to $\mathrm{pH} 8.3$ by adding $5 \mathrm{M}-\mathrm{NaOH}$. The supernatant fraction was used for the assay. A sample $(80 \mu \mathrm{l})$ of treated sample supernatant fraction was mixed with $0.1 \mathrm{U}$ ACE solution $(20 \mu \mathrm{l}) / \mathrm{ml}$ and $20 \mu \mathrm{l} 0.2 \mathrm{M}$-borate buffer ( $\mathrm{pH} 8.3$ ) containing $5 \mathrm{~mm}$-hippurl-L-histidyl-L-leucine (Sigma, St Louis, MO, USA) and $0.3 \mathrm{M}-\mathrm{NaCl}$. After incubation at $37^{\circ} \mathrm{C}$ for $30 \mathrm{~min}$, the reaction was stopped by adding $1 \mathrm{M}-\mathrm{HCl}(250 \mu \mathrm{l})$. The hippuric acid liberated from hippurl-L-histidyl-L-leucine by the enzymic action of ACE was extracted with ethyl acetate and was determined photometrically at $228 \mathrm{~nm}$. The coefficient of ACE inhibitory activity $\left(\mathrm{IDR}_{50}\right)$ was defined as the dilution ratio of the sample needed to inhibit the ACE activity by $50 \%$.

\section{Preparation of peptides fraction from $\gamma$-aminobutyric acid- enriched fermented milk}

FMG was centrifuged at $6000 \mathrm{~g}$ for $10 \mathrm{~min}$, and $10 \mathrm{ml}$ supernatant fraction was loaded onto a Bond-Elute $\mathrm{C}_{18}$ chromatography cartridge (Varian Inc., Harbor City, CA, USA). The solution that flowed through the chromatograph was collected as the unadsorbed fraction of FMG. After the cartridge had been washed with water, peptides were eluted with $60 \%$ acetonitrile. The eluted fraction was evaporated to dryness, and the residual material was dissolved in $10 \mathrm{ml}$ purified water and was used for ACE inhibitory assays as the peptide fraction of FMG.

\section{Statistical analyses}

Statistical analyses were performed using SAS Systems version 6.12 (SAS Institute Inc., Cary, NC, USA). Initial body weight and resting blood pressure data were analysed by Student's $t$ test to compare the SHR and WKY groups.
One-way ANOVA was used to compare the ACE inhibitory activity, dose-response, body weight and food intake among the three diet groups during chronic administration. When the variance ratio $(F)$ was significant, mean values were compared by Dunnett's test or the William's test. Two-way ANOVA was used to compare the result profiles over time with respect to blood pressure in single- and chronic-administration experiments. When the variance ratio $(F)$ was significant among groups, mean values were compared by Fisher's least significant difference test. All results are reported as mean values with their standard errors. All statistical analyses were two-tailed, and statistical significance was established at $P<0 \cdot 05$.

\section{Results}

Effect of a single oral dose of $\gamma$-aminobutyric acid-enriched fermented milk on blood pressure in spontaneously hypertensive/Izm and Wistar-Kyoto/Izm rats

Before dosing, the average body weight and resting SBP in SHR/Izm and WKY/Izm rats were as shown in Table 3. There was a significant difference in SBP between SHR/ Izm and WKY/Izm $(P<0 \cdot 01)$, but not in body weight. The effects of a single oral dose of FMG $(5 \mathrm{ml} / \mathrm{kg}$; equivalent to $0.5 \mathrm{mg}$ GABA $/ \mathrm{kg})$, GABA $(0.5 \mathrm{mg} / \mathrm{kg})$ or skimmed milk solution $(5 \mathrm{ml} / \mathrm{kg}$; GABA-free) on SBP are shown in Fig. 1. In SHR/Izm rats (Fig. 1(A)), two-way ANOVA showed independent effects of group $(P<0.05)$ and time $(P<0.01)$ : SBP $(\mathrm{mmHg}) 4 \mathrm{~h}$ after administration were 191.7 (SEM 3.5) for the control group (saline), 177.8 (SEM 4.7) for the FMG group $(P<0.05)$ and 177.7 (SEM 3.2) for the GABA group $(P<0.05)$; SBP $(\mathrm{mmHg}) 8 \mathrm{~h}$ after administration were 191.3 (SEM 2.1), 177.2 (SEM 4.4) $(P<0.05)$ and $178.5($ SEM 3.4) $(P<0.05)$ respectively. SBP returned to the baseline value by $24 \mathrm{~h}$ after dosing. In comparison, FMG and GABA did not change the SBP in WKY/Izm rats (Fig. 1(B)). Skimmed milk solution did not affect SBP in either strain of rats. There were no significant changes in heart rate after administration of FMG, GABA or skimmed milk solution in any animals (results not shown).

Dose-responsive hypotensive effect of single administration of $\gamma$-aminobutyric acid

Fig. 2 shows the hypotensive effects of different doses of GABA at $4 \mathrm{~h}$ after a single oral dose. Administration of GABA doses of 0.50 and $5.00 \mathrm{mg} / \mathrm{kg}$ (but not $0.05 \mathrm{mg} / \mathrm{kg}$ )

Table 3. Body weight and resting blood pressure in spontaneously hypertensive (SHR/lzm) and normotensive Wistar-Kyoto (WKY/Izm) rats (14 weeks old) at the beginning of Expt $1 \dagger$

(Mean values with their standard errors for six rats per group)

\begin{tabular}{llllll}
\hline & \multicolumn{2}{c}{ SHR/Izm } & & \multicolumn{2}{c}{ WKY/Izm } \\
\cline { 2 - 3 } \cline { 6 - 6 } \cline { 6 - 7 } & Mean & SEM & & Mean & SEM \\
\hline Body weight $(\mathrm{g})$ & $333 \cdot 8$ & 6.0 & & $353 \cdot 3$ & 6.1 \\
Resting SBP $(\mathrm{mmHg})$ & $195.3^{\star \star}$ & 2.4 & & 123.1 & 3.0 \\
\hline
\end{tabular}

Mean value was significantly different from that for WKY/Izm rats: ${ }^{\star \star} P<0.01$. †For details of diets and procedures, see Table 1 and pp. 412-413. 

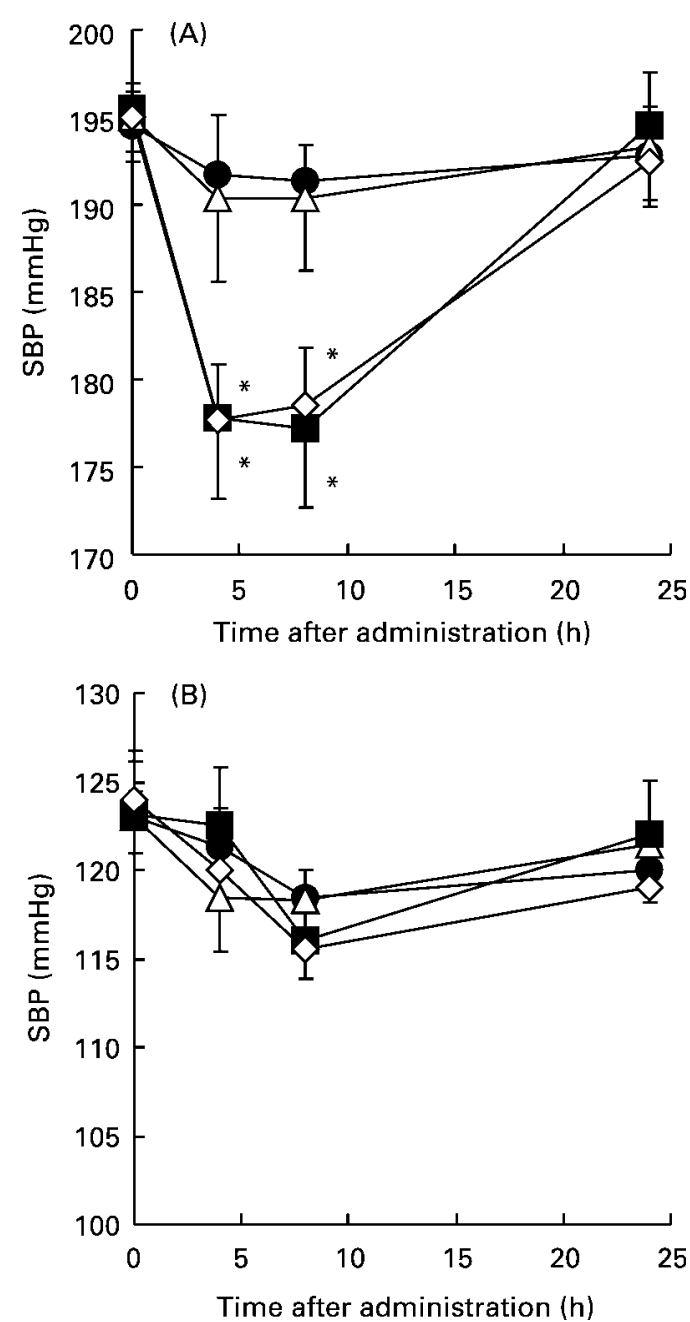

Fig. 1. Effect of a single oral administration of $\gamma$-aminobutyric acidenriched fermented milk (FMG) or $\gamma$-aminobutyric acid (GABA) on systolic blood pressure (SBP) in spontaneously hypertensive/lzm (A) and Wistar-Kyoto//zm rats (B). The doses of saline $(9 \mathrm{~g} \mathrm{NaCl} / \mathrm{l}$;

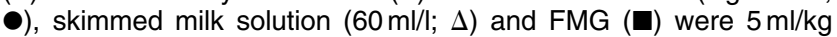
body weight, and for GABA $(\diamond)$ the dose was $0.5 \mathrm{mg} / \mathrm{kg}$. For details of diets and procedures, see Table 1 and p. 412. Values are means with their standard errors for six animals per group. Mean values were significantly different from that of the control (saline) value at the same time point: ${ }^{*} P<0.05$.

significantly $(P<0.05)$ decreased SBP. The hypotensive effect of GABA was dose-dependent from 0.05 to $5.00 \mathrm{mg} / \mathrm{kg}(r$ 0.972).

Angiotensin I-converting enzyme inhibitory activity and effect on systolic blood pressure of $\gamma$-aminobutyric acidenriched fermented milk and its peptide-containing fraction given as a single dose

Table 4 shows the ACE inhibitory activities and bloodpressure-lowering effects in SHR/Izm of FMG and its peptide-containing fraction. Captopril (an ACE inhibitor) as a positive control showed a strong ACE inhibitory effect and lowered the SBP significantly. In contrast, FMG, both its fractions, and GABA did not inhibit ACE activity, but SBP was significantly decreased compared with the saline control at $4 \mathrm{~h}$ after administration of FMG, the unadsorbed

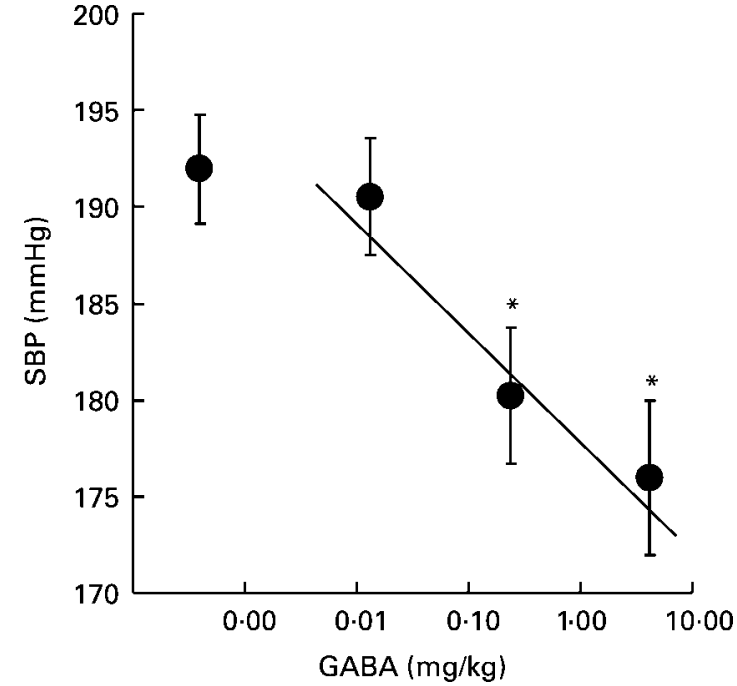

Fig. 2. Dose response of antihypertensive effect of $\gamma$-aminobutyric acid (GABA; non-linear scale) in spontaneously hypertensive/lzm rats. SBP, systolic blood pressure measured $4 \mathrm{~h}$ after administration of a single oral dose $(5 \mathrm{ml} / \mathrm{kg}$ body weight). For details of diets and procedures, see Table 1 and pp. 412-413. Values are means with their standard errors for six animals per group. Mean values were significantly different from that of the control (saline, $9 \mathrm{~g} \mathrm{NaCl} / \mathrm{l}$ $(0.00 \mathrm{mg} \mathrm{GABA} / \mathrm{kg}))$ value: ${ }^{*} P<0.05$.

Table 4. Angiotensin-I converting enzyme (ACE) inhibitory activity and antihypertensive effects of $\gamma$-aminobutyric acid-enriched fermented milk (FMG) and its fractions

(Mean values with their standard errors for six rats per group)

\begin{tabular}{|c|c|c|c|}
\hline & \multirow{2}{*}{$\begin{array}{c}\mathrm{IDR}_{50} \text { of } \mathrm{ACE} \\
\text { inhibition }\end{array}$} & \multicolumn{2}{|c|}{$\mathrm{SBP}(\mathrm{mmHg}) \ddagger$} \\
\hline & & Mean & SEM \\
\hline \multicolumn{4}{|l|}{ FMG } \\
\hline Whole & 0.1 & $178 \cdot 2^{*}$ & $5 \cdot 2$ \\
\hline Peptide fraction & $<0.1$ & $191 \cdot 8$ & $3 \cdot 2$ \\
\hline Unadsorbed fraction§ & $<0.1$ & $176 \cdot 5^{\star}$ & 2.9 \\
\hline $\mathrm{GABA}(1 \mathrm{mmol} / \mathrm{l})$ & $<0.1$ & $178 \cdot 0^{\star}$ & $3 \cdot 3$ \\
\hline Captopril $(0.5 \mathrm{mmol} / \mathrm{l})$ & $>1000$ & $178 \cdot 3^{\star}$ & 3.9 \\
\hline Saline $(9 \mathrm{~g} \mathrm{NaCl} / \mathrm{l})$ & $<0.1$ & 191.9 & 2.9 \\
\hline
\end{tabular}

$\mathrm{IDR}_{50}$, dilution ratio of sample needed to inhibit ACE activity by $50 \%$; SBP, systolic blood pressure; GABA, $\gamma$-aminobutyric acid.

Mean values were significantly different from that of the saline group (control): ${ }^{*} P<0.05$

†For details of procedures, see Table 1 and p. 412.

$\ddagger$ The SBP of spontaneously hypertensive /Izm rats was measured $4 \mathrm{~h}$ after a single oral dose $(5 \mathrm{ml} / \mathrm{kg}$ body weight; at time $0 \mathrm{~h}$, SBP 195.3 (SEM 2.4) $\mathrm{mmHg}$ ).

$\S$ The fraction of FMG that was not adsorbed on reverse-phase chromatography and that included $1 \mathrm{mmol}$ GABA/l.

fraction of FMG, GABA or captopril $(P<0 \cdot 05)$. The peptide fraction of FMG showed neither ACE inhibitory activity nor blood-pressure-lowering effects. The profile of blood pressure change due to administration of the non-adsorbed fraction of FMG was very similar to that for FMG in SHR/Izm (Fig. 3).

Chronic administration of $\gamma$-aminobutyric acid-enriched fermented milk or $\gamma$-aminobutyric acid

The body weight and food intake of SHR/Izm in Expt 2 are shown in Table 5. There were no significant differences in 


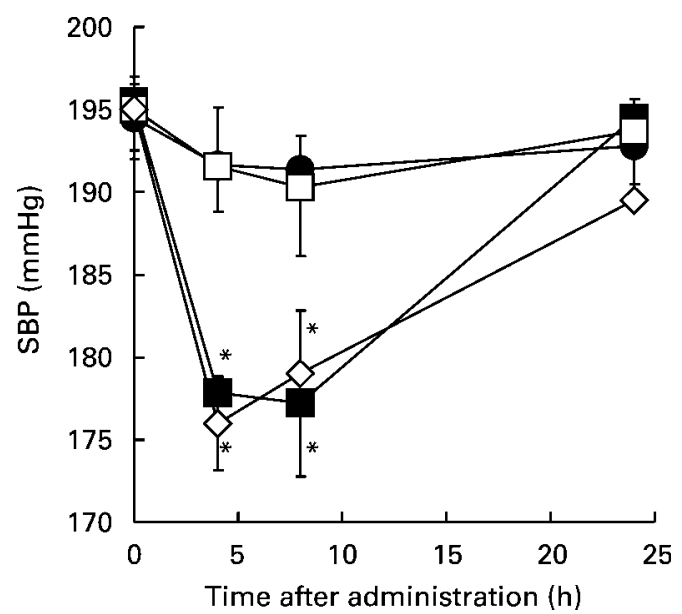

Fig. 3. Effect of a single oral administration of fractions of $\gamma$-aminobutyric acid-enriched fermented milk (FMG) on systolic blood pressure (SBP) in spontaneously hypertensive (SHR)/lzm rats. $\bullet$, Saline $(9 \mathrm{~g} \mathrm{NaCl} / \mathrm{l}) ; \square$, FMG (peptide fraction); $\diamond$, FMG (without peptide fraction); $\mathbf{\square}, \mathrm{FMG}$ (whole). The dose was $5 \mathrm{ml} / \mathrm{kg}$ body weight. For details of diets and procedures, see Table 1 and pp. 412-413. Values are means with their standard errors for six animals per group. Mean values were significantly different from that of the control (saline) value at the same time point: ${ }^{*} P<0.05$

these values between the three groups. The time course of SBP during the experiment is shown in Fig. 4. The SBP increased gradually with age and reached $>200 \mathrm{mmHg}$ at 10 weeks of age in the control group. A significantly slower increase in SBP compared with the control group was observed 1 or 2 weeks after the start (at 7 weeks of age) of feeding with the GABA or FMG diet respectively $(P<0.05)$, and this difference was maintained throughout the period of feeding. After 3 weeks of feeding the experimental diets, SBP values $(\mathrm{mmHg})$ in the control, GABA and FMG groups were 199.8 (SEM 3.8), 184.9 (SEM 1.4) $(P<0.01 v$. control group) and 182.8 (SEM 2.4) $(P<0.01$ $v$. control group) respectively. There were no significant changes in heart rate in the control, FMG or GABA groups (results not shown).

\section{Discussion}

FMG and the identical amount of reagent GABA had a similar magnitude of hypotensive effect by single-dose and chronic administration to SHR/Izm. We also previously reported that FMG has a hypotensive effect in patients having mild hypertension (Inoue et al. 2003), although it was not clear whether the effect depended on

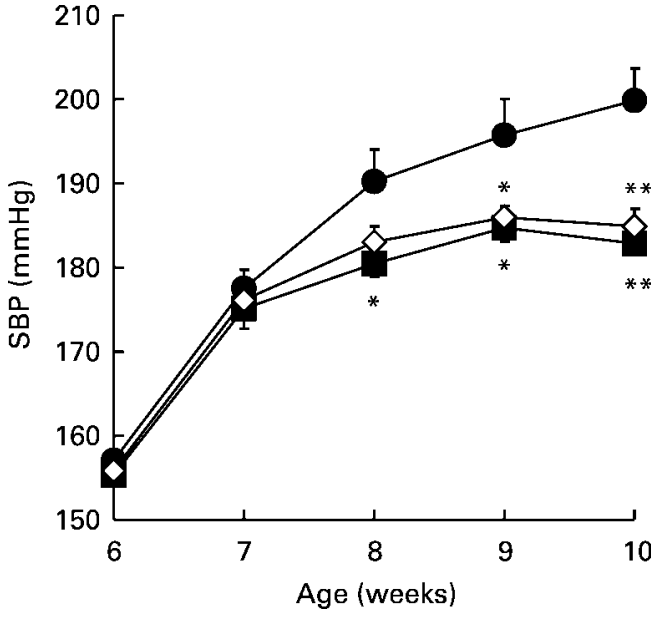

Fig. 4. Effect of chronic administration of $\gamma$-aminobutyric acidenriched fermented milk (FMG) or $\gamma$-aminobutyric acid (GABA) on systolic blood pressure (SBP) in spontaneously hypertensive/lzm rats. $\bullet$, Control; $\boldsymbol{\square}, \mathrm{FMG} ; \diamond$, GABA. Test diets were fed from 7 to 10 weeks of age. For details of diets and procedures, see Tables 1 and 2 and pp. 412-413. Values are means with their standard errors for ten animals per group. Mean values were significantly different from that of the control value at the same time point: ${ }^{\star} P<0.05$.

GABA. However, it seems reasonable to conclude that the hypotensive effect of FMG was caused by GABA. After a single oral dose of GABA (about $7 \mathrm{mg} / \mathrm{kg}$ ) was given to rats (body weight $350 \mathrm{~g}$ ), the plasma GABA concentration peaked $(1.4 \mu \mathrm{g} / \mathrm{ml})$ after $1 \mathrm{~h}$, then decreased gradually to $0.8 \mu \mathrm{g} / \mathrm{ml}$ after $6 \mathrm{~h}$, and disappeared after $24 \mathrm{~h}$ (Nakamura et al. 2000). In our present experiment, the hypotensive effect of GABA continued until $8 \mathrm{~h}$ after oral administration, and the effect disappeared after $24 \mathrm{~h}$. There was good correlation between the plasma GABA level and the hypotensive effect (Fig. 1).

Many studies have linked increased long-term consumption of milk and dairy products with decreased blood pressure and reduced risk of hypertension. For example, a study of 5000 people found that those with normal blood pressure reported higher consumption of milk than did hypertensive subjects (Ackley et al. 1983). The authors suggested that some component of milk, probably $\mathrm{Ca}$, exerted a protective effect against hypertension. In a recent review, the Dietary Approaches to Stop Hypertension (DASH) diet (a diet high in low-fat dairy foods, fruits and vegetables) reduced blood pressure (Appel et al. 1997; Miller et al. 2000). However, the hypotensive effect of milk is small (Allender et al. 1996), and a single oral dose of skimmed

Table 5. Body weight and food intake of rats in Expt $2^{*}$

(Mean values with their standard errors for ten rats per group)

\begin{tabular}{|c|c|c|c|c|c|c|c|}
\hline \multirow{2}{*}{$\begin{array}{l}\text { Diet... } \\
\text { Variable }\end{array}$} & \multicolumn{2}{|c|}{ Control } & \multicolumn{2}{|c|}{ GABA } & \multicolumn{2}{|c|}{ FMG } & \multirow{2}{*}{$\begin{array}{c}\text { Statistical significance of } \\
\text { effect (one-way ANOVA): } P \\
\end{array}$} \\
\hline & Mean & SEM & Mean & SEM & Mean & SEM & \\
\hline \multicolumn{8}{|l|}{ Body weight (g) } \\
\hline 7 weeks old & 184.4 & 1.9 & 182.5 & $2 \cdot 1$ & $180 \cdot 9$ & $2 \cdot 0$ & 0.482 \\
\hline 10 weeks old & 264.7 & 5.4 & $271 \cdot 0$ & 2.5 & 268.9 & $2 \cdot 5$ & 0.545 \\
\hline Food intake (g per rat in 3 weeks) & 350.7 & 19.5 & 362.5 & $16 \cdot 2$ & 361.5 & $18 \cdot 2$ & 0.805 \\
\hline
\end{tabular}

GABA, $\gamma$-aminobutyric acid; FMG, $\gamma$-aminobutyric acid-enriched fermented milk.

${ }^{*}$ For details of diets and procedures, see Tables 1 and 2 and p. 412 . 
milk had no blood-pressure-lowering effect in SHR/Izm in our present study.

Some studies reported that in both single-dose and long-term regimens, various fermented milk or cheese products had stronger hypotensive effects than milk (Nakamura et al. 1995; Yamamoto et al. 1999; Saito et al. 2000; Seppo et al. 2003). Some lactic acid bacteria produce peptides that are released from the protein of the milk by proteolysis and inhibit ACE, which is instrumental in inducing hypertension (Nakamura et al. 1995; Yamamoto et al. 1999). It seemed reasonable to think that the hypotensive effect of FMG was related to inhibition of ACE. However, we found that neither FMG nor its peptide fraction showed any substantial inhibition of ACE activity. Nor did the peptides of FMG have a hypotensive effect after their oral administration to SHR/Izm rats. Furthermore, the two starters used to produce FMG, Lactobacillus casei strain Shirota and Lactococcus lactis YIT 2027, did not generate any hypotensive peptides from the protein of the milk. These and our other results indicate that the hypotensive effect of FMG is closely related to the presence of GABA.

During fermentation to produce FMG, GABA is made from the protein of the milk by Lactococcus lactis YIT 2027, which has strong glutamate decarboxylase activity. From the point of view of GABA production, acidic fermented milk is beneficial, because the glutamate decarboxylase activity of Lactococcus lactis YIT 2027 is optimal at about pH 5.3 (K Hayakawa et al., unpublished results); its GABA transaminase (optimal pH 8-10; Shelp et al. 1999), which catalyses the transformation of GABA to succinic semialdehyde, is poorly active under acidic conditions. Therefore, GABA accumulates during fermentation.

Although the mechanism of the hypotensive action of systemically administered GABA has not been fully elucidated, several hypotheses have been postulated. Because GABA barely passes the blood-brain barrier (Gelder \& Elliott 1958; Kuriyama \& Sze 1971), it is reasonable to consider that, at low doses, GABA cannot act centrally but only peripherally. In practice, GABA inhibits noradrenaline release from sympathetic nerve terminals in the mesenteric arterial bed in SHR/Izm rats (Hayakawa et al. 2002). It has been suggested that this effect is mediated through peripheral activation of the $\mathrm{GABA}_{B}$ receptor, because the hypotensive effect is reduced by preadministration of the $\mathrm{GABA}_{\mathrm{B}}$ receptor antagonist saclofen.

Several recent studies have reported that various GABAcontaining dietary materials or products decrease blood pressure in SHR and hypertensive patients. Gabaron tea (anaerobically fermented tea; Oomori et al. 1987), extracts of beni-koji (Tsuji et al. 1992) and a particular defatted rice germ (Onoda et al. 1998) are included among these supplements. However, these dietary materials and products contain many ingredients besides GABA, whose effects were not ruled out, although it was presumed that the hypotensive effect was due to the presence of GABA.

In a previous study, we investigated the safety of FMG in healthy adults with normal blood pressure (Kimura et al. 2002a). Administration of $100 \mathrm{ml} \mathrm{FMG/d} \mathrm{for} 8$ weeks and $300 \mathrm{ml} / \mathrm{d}$ for 2 weeks failed to induce any changes in normal blood pressure and heart rate. In addition, we observed no remarkable changes in haematological and biochemical indices. It is important that FMG has no effect on normal blood pressure in human subjects, as it is undesirable to reduce blood pressure further than the level needed. In the present animal study, we observed a similar effect, in that FMG did not affect blood pressure in normotensive WKY/Izm rats; FMG exhibited a hypotensive effect only in the SHR/Izm.

In conclusion, our present results clearly show that our novel GABA-containing fermented milk product significantly reduced blood pressure in SHR/Izm rats. We consider that the hypotensive effect of FMG depends on GABA. Therefore, our FMG will probably be a beneficial addition to the diets of people with essential hypertension. The low incidence of hypertension among vegetarians may be partly attributable to their ingestion of GABA via these foods; however, further studies are required to confirm this theory.

\section{Acknowledgements}

We thank Mr S. Thuchikura (Disease Model Cooperative Research Association, Kyoto, Japan) for his skilled technical assistance, and the staff of our laboratory animal facility for their careful maintenance of the rats.

\section{References}

Ackley S, Barrett CE \& Suarez L (1983) Dairy products, calcium, and blood pressure. Am J Clin Nutr 38, 457-461.

Akita S, Sacks FM, Svetkey LP, Conlin PR \& Kimura G (2003) Effects of the Dietary Approaches to Stop Hypertension (DASH) diet on the pressure-natriuresis relationship. Hypertension 42, 8-13.

Allender PS, Cutler JA, Follmann D, Cappucio FP, Pryer J \& Elliott P (1996) Dietary calcium and blood pressure: a metaanalysis of randomized clinical trials. Ann Intern Med 124, $825-831$.

Appel JL, Moore JT, Obarzanek E, et al. (1997) A clinical trial of the effects of dietary patterns on blood pressure. New Engl J Med 336, 1117-1124.

Cushman WD \& Cheung SH (1971) Spectrophotometric assay and properties of the angiotensin-converting enzyme of rabbit lung. Biochem Pharmacol 20, 1637-1648.

Elliott CAK \& Hobbiger F (1959) Gamma aminobutyric acid: circulatory and respiratory effects in different species: re-investigation of the anti-strychnine action in mice. $J$ Physiol 146, 70-84.

Gelder VMN \& Elliott CAK (1958) Disposition of $\gamma$-aminobutyric acid administered to mammals. $J$ Neurochem 3, 139-143.

Guidelines Subcommittee of the World Health OrganizationInternational Society of Hypertension (1999) 1999 World Health Organization-International Society of Hypertension guidelines for the management of hypertension. $J$ Hypertens 17, 151-183.

Hayakawa K, Kimura M \& Kamata K (2002) Mechanism underlying $\gamma$-aminobutyric acid-induced antihypertensive effect in spontaneously hypertensive rats. Eur $J$ Pharmacol 428, $107-113$.

Inoue K, Shirai T, Ochiai H, Kasao M, Hayakawa K, Kimura M \& Sansawa H (2003) Blood-pressure-lowering effect of a novel fermented milk containing $\gamma$-aminobutyric acid (GABA) in mild hypertensives. Eur J Clin Nutr 57, 490-495. 
International Society of Hypertension Working Group (2003) International Society of Hypertension (ISH): Statement on blood pressure lowering and stroke prevention. J Hypertens 21, 651-663.

Kimura M, Chounan O, Takahashi R, Ohashi A, Arai Y, Hayakawa K, Kasaha K \& Ishihara C (2002a) Effect of fermented milk containing $\gamma$-aminobutyric acid on normal adult subjects. Jpn J Food Chem 9, 1-6.

Kimura M, Hayakawa K \& Sansawa H (2002b) Involvement of $\gamma$-aminobutyric acid (GABA) B receptors in the hypotensive effect of systemically administrated GABA in spontaneous hypertensive rats. Jpn J Pharmacol 89, 388-394.

Kuriyama K \& Sze PY (1971) Blood-brain barrier to ${ }^{3} \mathrm{H}$ - $\gamma$-aminobutyric acid in normal and amino oxyacetic acid-treated animals. Neuropharmacology 10, 103-108.

Lacerda CEJ, Campos RR, Araujo CG, Andreatta-Van Leyen S, Lopes OU \& Guertzenstein PG (2003) Cardiovascular responses to microinjections of GABA or anesthetics into the rostral ventrolateral medulla of conscious and anesthetized rats. Braz J Med Biol Res 36, 1269-1277.

Miller GD, DiRienzo DD, Reusser ME \& McCarron DA (2000) Benefits of dairy product consumption on blood pressure in humans: a summary of the biomedical literature. J Am Coll Nutr 19, 147S-164S.

Moore TJ, Conlin PR, Ard J \& Svetkey LP (2001) DASH (Dietary Approaches to Stop Hypertension) diet is effective treatment for stage 1 isolated systolic hypertension. Hypertension 38, 155-158.

Nakamura H, Matsubara T, Kamachi K, Hasegawa S, Ando Y \& Oomori S (2000) Antihypertensive effect of GABA-rich Clorella in spontaneously hypertensive rats. Nihon-NougeiKagakukaishi 74, 74.

Nakamura Y, Yamamoto N, Sakai K, Okubo A, Yamazaki S \& Takano T (1995) Purification and characterization of angiotensin I-converting enzyme inhibitor from sour milk. J Dairy Sci 78, 777-783.

Okamoto \& Aoki (1963) Development of a strain of spontaneously hypertensive rats. Jpn Circ J 27, 282-293.

Onoda A, Saikusa T, Horino T, Kajimoto O, Miyamoto A,
Tanaka Y, Murakami T, Okada T \& Murai H (1998) Accumulative effect of $\gamma$-aminobutyric acid (GABA) for defatted rice germ. The first international symposium on disease prevention by IPS and other rice components. Abstracts, p. 97.

Oomori S, Yano T, Okamoto J, Tsushida T, Murai T \& Higuchi M (1987) Effect of anaerobically treated tea (Gabaron tea) on the blood pressure of spontaneously hypertensive rats. Nippon Nogeikagaku Kaishi 61, 1449-1451.

Saito T, Nakamura T, Kitazawa H, Kawai Y \& Itoh T (2000) Isolation and structural of antihypertensive peptides that exist naturally in gouda cheese. J Dairy Sci 83, 1434-1440.

Seppo L, Jauhiainen T, Poussa T \& Korpela R (2003) A fermented milk high in bioactive peptides has a blood pressure-lowering effect in hypertensive subjects. Am J Clin Nutr 77, 326-330.

Shelp JB, Bown WB \& McLean DM (1999) Metabolism and functions of gamma-aminobutyric acid. Trends Plant Sci $\mathbf{4}$ $1360-1385$.

Stanton HC (1963) Mode of action of gamma amino butyric acid on the cardiovascular system. Arch Int Pharmacodyn Ther 143, 195-204.

Suter PM, Sierro C \& Vetter W (2002) Nutritional factors in the control of blood pressure and hypertension. Nutr Clin Care 5, 9-19.

Takahashi H, Tiba M, Iino M \& Takayasu T (1955) The effect of $\gamma$-aminobutyric acid on blood pressure. Jpn J Physiol 5, 334-341.

Tsuji K, Ichikawa T, Tanabe N, Abe S, Tarui S \& Nakagawa Y (1992) Antihypertensive activities of Beri-Koji extracts and $\gamma$-aminobutyric acid in spontaneously hypertensive rats. Jpn $J$ Nutr 50, 285-291.

Whelton PK, He J, Appel LJ, et al. (2002) Primary prevention of hypertension: clinical and public health advisory from the National High Blood Pressure Education Program. J Am Med Assoc 288, 1882-1888.

Yamamoto N, Maeno M \& Takano T (1999) Purification and characterization of an antihypertensive peptide from a yogurtlike product fermented by Lactobacillus helveticus CPN4. J Dairy Sci 82, 1388-1393. 